\title{
INSTITUTIONALIZATION OF RESIDENTIAL PROPERTY MANAGEMENT IN POLAND ${ }^{1}$
}

\author{
Adam Nalepka \\ Department of Economics for Real Estate and Investment Process \\ Cracow University of Economics \\ e-mail:nalepkaa@uek.krakow.pl
}

\begin{abstract}
The management of residential properties has its specificity which primarily arises from their constant inhabitation by users, which requires the permanent provision of specific services to flats. This specificity is also significantly influenced by legal regulations which residential real estates are subject to, which vary according to the various forms of ownership and types of residential units.

This paper pays special attention to the organizational and legal forms applicable in residential property management in Poland.

The undertaken attempt to find a comprehensive approach to the problem of the institutionalization of residential property management in Poland is a good starting point for in-depth research into the effectiveness and efficiency of individual institutional forms.
\end{abstract}

Key words: property management, residential property, institutional management forms.

JEL Classification: A13.

Citation: Nalepka A., 2015, Institutionalization of Residential Property Management in Poland, Real Estate Management and Valuation, Vol. 23, No. 4, pp. 44-51.

DOI: 10.1515/remav-2015-0035

\section{Introductory remarks}

Property management consists of the proper technical maintenance and rational usage of construction and technical facilities, serving various utility, social and economic functions.

Residential properties occupy a special position among real estate. The source of the specificity connected with managing residential properties is primarily the fact that they are constantly inhabited by users. This requires the uninterrupted provision of specific services to flats, e.g.: water, electricity, heating, gas, solid and liquid waste removal, cleaning, maintenance, repairs, construction, etc. What is also significant in this respect are legal regulations which residential property management is subject to, different for various forms of ownership, types of residential units, their structure and equipment.

The aim of this paper is to identify, classify and characterize the organizational and legal forms of residential property management in Poland.

The starting point for the discussion is the characterization of the ownership structure of Poland's housing resources, which indicates the diversity and real significance of various institutional forms of residential property management.

The framework of this paper does not enable the full presentation of issues related to the institutionalization of managing various forms of residential properties ${ }^{2}$. However, the undertaken

\footnotetext{
1 The publication has been financed with subsidies granted to the Faculty of Economics and International Relations of the Cracow University of Economics to maintain research capacity.

2 The problems connected with the institutionalization of residential property management in Poland are presented much more broadly in the paper titled: Wspótczesne problemy zarzadzania nieruchomościami mieszkaniowymi, a collective work edited by Adam Nalepka, Cracow University of Economics, Faculty of
} 
attempt at a comprehensive and systematic approach to the problem of the institutionalization of managing residential properties in Poland can be, it seems, a convenient starting point for more indepth research into this problem.

\section{Specific problems of residential property management}

Residential properties are building properties with a prevailing housing function, of various structure, often including commercial or service units, garages, storage rooms in basements or free standing units, etc. The properties can be equipped with numerous installations and equiptment providing the facility with specific functionality and comfort. This is particularly visible in newly-built residential buildings (KAMIŃSKI 2014).

Residential property management must enable permanent inhabitation by people. The specific nature of managing housing resources arises from the variety of ownership forms and legal titles of governing properties. The table below presents the current ownership structure of housing resources in Poland.

Table 1

Ownership structure of housing resources in Poland (as of 31.12.2013)

\begin{tabular}{lcr}
\hline \multicolumn{1}{c}{ Specification } & Number of flats & Share $\%$ \\
\hline total & $13,852,896$ & 100.0 \\
\hline housing co-operatives & $2,248,625$ & 16.2 \\
\hline municipalities (council flats) & 934,863 & 6.7 \\
\hline firms & 105,304 & 0.8 \\
\hline the Treasury & 30,527 & 0.2 \\
\hline social housing associations & 92,66 & 0.7 \\
\hline natural persons & $10,441,511$ & 75.4 \\
\hline including: & & 18.2 \\
\hline - tenants' associations & $2,523,692$ & 57.2 \\
\hline - outside tenants' associations & $7,917,819$ & \\
\hline
\end{tabular}

Source: own study based on: Managing housing in 2013, Central Statistical Office Warsaw 2014.

The specific character of residential property management also arises from the division of the area of the property into premises (residential and utility ones) being at the users' (owners', tenants') disposal, and shared areas. Thus, operating residential property management consists of managing individual premises, which, as a rule, is implemented by the users, and managing shared parts, implemented by the property manager.

The specificity of residential property management is also influenced by the motives for investing in and the underlying goals behind possessing real estate.

Numerous entities operate in the area of residential property management in Poland (NALEPKA 2013, p. 17 onwards):

- housing co-operatives,

- organizational units of municipalities,

- firms and state institutions, holding flats for their employees,

- social housing associations,

- tenants' associations,

- private owners of detached houses and tenement houses,

- specialized firms managing properties.

These entities have developed a number of organizational and legal forms of managing residential properties. They will be characterized in further parts of the paper.

Economics and International Relations, Department of Economics for Real Estate and Investment Processes, Kraków 2014 (Statutory Research No. 046/WE - KEN/01/2014/S/4242, unpublished material). 


\section{Entities managing residential properties}

\subsection{Housing co-operatives}

Housing co-operatives are non-profit entities, conducting activities which aim basically at fulfilling the housing needs of their members and their families, managing these properties (BoŃCZAKKUCHARCZYK 2008, p. 337), and providing social, educational and cultural activities for their members and the local community (MYCZKOWSKI 1997, p. 145).

The way in which a housing co-operative operates, including the management of housing resources, is based on the provisions of the Housing Cooperatives Act (HCA, Article 1, Section 1), and the provisions of the housing cooperative statute.

The management functions of a housing co-operative are performed by the Management Board. Management tasks are divided among the President, his/her deputies, and subordinate organizational units. In the organizational structure of a housing co-operative, the following units can usually be distinguished: general, investment, housing resource management and accounting.

Considering the goal of the paper, attention will be focused on the housing resource management unit. It implements the operating management of residential properties of the co-operative. The tasks are implemented by appropriate units and organizational positions, some examples of which include:

- the housing resources management department, which deals with maintaining the shared parts of the property,

- the housing estate administrations being in direct contact with the residents and their environment,

- the technical unit, which deals with periodical inspections of equipment and installations, as well as their day-to-day maintenance and carrying out small repairs in the buildings,

- the heating department which supplies hot water and central heating to the buildings of the housing co-operative. In order to do so, it can use its own boiler-houses,

- the repair and renovation department, which establishes repair and renovation needs, organizes repairs using its own resources or contracting them out to external companies, and carries out the acceptance of repair and modernization works.

The organizational units of the housing resources management department are supported by various positions and organizational units of the remaining organizational units of the housing cooperative.

\subsection{Organizational units of municipalities}

The aim of council housing resources is to meet the housing needs of low-income households.

Municipalities have developed a number of organizational forms of managing council residential properties (CIEPIELA 2001). The management of municipal residential properties is usually entrusted to self-governmental budgetary establishments, budgetary units, municipal companies or social housing associations.

Self-governmental budgetary establishments (single or multi-business ones) manage residential properties based on the resolution of the municipality council, assigning a budgetary entity and defining the subject of its activities. In practice, we do not come across cases of concluding property management contracts between a municipality and its own budgetary entity. A budgetary entity, as an entity managing council residential properties, does not have a legal personality. This hampers the independent carrying out of numerous matters related to effective resource management. A selfgovernmental budgetary establishment does not receive residential properties for permanent administration, which prevents it from using numerous instruments of financing modernizationdevelopment projects which are available on the market (PAWELEC 2003).

Municipalities also entrust residential property management to budgetary units. Budgetary units managing council residential properties usually arise as a result of the transformation of selfgovernmental budgetary establishments. Such decisions are taken when a municipality approaches the "debt threshold". This transformation makes it possible to increase revenues to the municipal budget (gross budgeting of budgetary units) and reduce the share of credits in the municipal income, averting the risk of compulsory administration. The principles of managing council residential properties by budgetary units are basically the same as in the case of budgetary establishments.

Managing housing resources of the municipality is entrusted to single-person companies of the municipality (municipal companies) (SZCZEPANIAK 2013), joint stock companies or limited liability 
companies. The established company manages residential properties of the municipality based on the order to take over their management, issued by the city mayor (president) (PAWELEC 2003). In practice, cases of concluding "property management agreements" between the municipal bodies and the established municipal company are extremely rare. Contributions-in-kind of managed residential properties are not made to municipal companies, which brings about similar negative consequences as in the case of a budgetary establishment.

A special role in managing council residential properties is performed by social housing associations, owned or co-owned by the municipality. The municipality can hand over the management of municipal residential properties to social housing associations based on the contract of mandate (ASRC, Article 27, section 2, subsection 4).

Municipalities can also contract the management of council residential properties out to professional property management firms. This leads to the privatization of the management process. Then, the Municipality Council works out a housing strategy and formulates a policy of financing council housing management, the President of the municipality establishes the principles and tools of municipal residential property management, and specialized departments of the Municipal Office arrange the management, choosing specialized firms managing residential properties in tenders, and supervise the activities of such firms. Municipal bodies supervise the process and assess the scope and quality of the tasks performed. The selected firms operate outside the municipality structures, which enables the ownership functions to be separated from the function of managing residential properties of municipalities.

\subsection{Firms}

Residential properties, commonly defined as "company flats", are residential units which used to be at the disposal of firms (enterprises) and were rented to their employees or other individuals performing work for the firms (LUTY 1992). Company flats were an instrument of the personnel policy of firms (state-owned, at the time), and were to attract highly qualified people to work in a given enterprise. The tenancy agreement for such a flat was concluded for the time of the employment relationship ${ }^{3}$.

Company residential properties were most often managed by:

- organizational units of these firms,

- ownership-dependent co-operatives or companies.

In the first case, the basic functions of residential property management were performed by employees, usually employed in HR or administration units, in separate departments or sections. The localization of these organizational units in the company structure, their name, staffing and scope of tasks were varied, dependent on the size of the managed housing resources. The scope of activities of these organizational units rarely included all functions of managing housing resources; therefore, the units cooperated with other organizational units of the company, which fulfilled tasks related to legal and financial matters, accounting, repair and maintenance, supply and transport services, as well as HR, social and training tasks.

In numerous firms, the tasks related to managing company residential properties were entrusted to ownership-dependent co-operatives or companies, which are organized in accordance with the subjective regulations.

\subsection{Social housing associations}

Social housing associations are one of the instruments of housing policy. The basic task of social housing associations is building houses with moderate rents, financed as a whole or in part from public funds (SZELĄGOWSKA 2011, p. 13), and their use on terms of lease (ASRC, Article 27). Associations can also manage residential buildings they do not own, pursuant to a contract for mandate.

Social housing associations can be established in three organizational and legal forms (ASRC, Article 23, section 1): limited liability companies, joint stock companies and co-operatives of legal persons. This means that a social housing association is an independent economic entity with a legal personality. The scope of activities of social housing associations includes investment and operating

\footnotetext{
${ }^{3}$ The Act on the Ownership of Premises of 24 June 1994 abolished the institution of company flats and equated the rights of tenants of former company flats and the rights of tenants of other residential units.
} 
activities. Operating activities of social housing associations consist of managing their own residential properties and residential properties of other owners, pursuant to contracts for mandate. The basis for financing operating activities is rent at the economic level, which covers the costs of the use of the property and the payment of credit. The revenues from the operating activities of social housing associations as non-profit organizations are accumulated for future investment in flats for rent, and not allocated for division among the partners or members. This is, as it seems, one of the basic reasons for the weak development of the social housing association system in Poland (SZELĄGOWSKA 2011, p. 299). It appears that enabling social housing associations to function for profit could stimulate them to operate more actively.

\subsection{Tenants' associations}

A tenants' association is a form of organization made up of the owners of residential units in multiunit buildings, functioning in Poland for a relatively short time, which aims to maintain the shared areas in proper condition and manage the property efficiently. It is created by virtue of law, upon the transfer of the ownership of the first isolated unit in a multi-unit building to another person (AOP). Tenants' associations can be created by public entities or natural persons who have purchased residential units (TURLEJ 2004, pp. 58-59). Matters of tenants' associations are settled by all the owners in the form of resolutions passed by the majority of votes of the owners of units or in accordance with the principle that one vote falls to one owner.

The Act on the Ownership of Premises differentiates between large and small tenants' associations. The difference between them consists primarily in the different form of managing shared areas (Lewandowski, 2004). In the case of a small association, the management functions can be performed directly by all unit owners. In a large tenants' association, the management function is performed by the association's body, referred to as the association management board, chosen by the resolution of the owners. It manages the matters of the association and represents it on the outside and in relationships between the association and individual unit owners (TURLEJ 2004, p. 128). The owners of residential units can also entrust the management of the shared areas of the property to a professional management firm. Establishing cooperation with a management firm can ensure the proper maintenance of the technical condition of the shared areas and appropriate comfort of residence. The choice of the form of shared area management assumed depends on the attitudes of the tenants' association members and their willingness to actively participate in the management process (GOSPODAROWANIE ... 2002, p. 65).

Separate ownership of the premise and, therefore, of the tenants' associations, can be established on residential properties:

- newly-created by developers,

- of municipalities privatizing council units,

- companies selling their residential units.

\subsubsection{Tenants' associations created in developer properties}

Upon the completion of the investment process, the developer isolates flats and commercial premises which can constitute separate ownership in order to sell them. When isolating and selling the first unit in the newly-created residential property, developers choose one of the following methods of managing the shared areas:

- undertaking the activities of managing the tenants' association - a so-called developer's administration,

- entrusting the management of the tenants' association to a property management firm which they have chosen themselves.

In the case of the successive sale of premises, the chosen way of managing the shared areas is usually imposed on each of the following buyers. It is binding for the next buyers of the premises until changed by the members of the association.

The developer decides to take over the obligations of managing the shared areas when (NAJBAR 2002):

- it is one of the objects of activity of the developer company,

- it is treated as a side, short-term activity, aimed at raising additional funds, 
- it is to provide control over the actions of unit owners with regard to potential claims arising from the emergence of physical defects of the building, which, under the terms of the warranty, the developer company is obliged to remove at its own expense,

- the developer wants to maintain full control over unfinished investments,

- there are problems with selling flats, and the necessity of an occasional lease occurs.

In this case, the developer undertakes all obligations related to property management, decides o the management costs, the amount of remuneration, and sometimes also about the duration of such kind of management. On the whole, developers' interest in managing tenants' associations is beginning to fall. This results mainly from the fact that the effective management of the created housing resources and the package of operations expected by the buyers of units turns out to be to too big of an organizational burden (the necessity of hiring experts) and a reason for an increase in the costs of management, higher than the profit from such activities.

Entrusting the management of shared areas to a specialized property management firm by the developer usually takes place when the developer is not interested in expanding its scope of activities, has sold most of the premises, and the costs of maintaining the shared areas it is encumbered with are relatively low. As a rule, such a firm is already known to the developer.

\subsubsection{Tenants' associations created in council properties}

As a result of the municipalization of state assets, municipalities have obtained substantial resources of residential properties. In the situation of legally restricted possibilities to establish the amount of rent for residential units and high costs of maintaining these properties, municipalities sell individual units. In consequence, municipalities become members of tenants' associations.

The associations can be managed in the transitional period by organizational units of the municipality, i.e. budgetary entities, budgetary units, or municipal companies which have managed the properties so far (AOP. Article 40, section 1). Such a situation can last only until the owners of the units order the principles of managing the shared areas in a proper manner. Then, the owners of the units can determine the way of managing the shared areas, and entrust management tasks to specialized property management firms.

\subsubsection{Tenants' associations created in company properties}

Due to the necessity for the permanent subsidization of residential property management, companies have begun to privatize their flats, at the same time becoming members of tenants' associations. The situation of numerous tenants' associations created on the basis of company housing resources is very unfavorable, with the main reason for this being the poor technical condition of the buildings.

The arising tenants' associations are most often managed by organizational units of the company or by isolated companies. As tenants' association members, firms try to control the management process in various ways to protect themselves against the unpredictable decisions of tenants' associations. The concern of members of tenants' associations regarding an increase in the costs of managing the shared areas due to a possible change of the manager is, in many cases, a motive for maintaining the company in the role of the association's manager.

\subsection{Private owners of detached houses and tenement houses}

In the case of managing private residential properties, we can indicate two different situations (BOŃCZAK-KUCHARCZYK 2003, p. 189).

The first situation is when the owner himself uses the property. The choice of the method and the scope of the implementation of tasks related to managing such a property depend on the owner. They are subject to his expectations, tastes and preferences. The owner himself takes decisions on maintaining, supplying and using the property, and often fulfills them on his own and makes necessary financial settlements. The owner of such a property does not keep books, and does not submit any reports to anyone, or any statistical information. He also creates plans for his property by himself, and implements a specific management strategy.

Another situation is when the owner manages the whole or a part of the property used by other people, based on tenancy agreements. Then, the owner has to additionally comply with the tenant protection regulations, fulfilling the general obligations of the lessor and others, agreed on in the tenancy agreement. He also has to fulfill tax obligations (on rent revenues) and reporting obligations. 


\subsection{Specialized property management firms}

The owner can contract the property management out to a specialized property management firm (NALEPKA, NAJBAR 2007). The basic document regulating the relationship between the owner and the management firm is a property management agreement (PRZYBYLSKI 2001). Such a firm implements chiefly the property owner's goals, agreed upon in the property management agreement, and, in particular, maintains and increases the real value of the property. The property management firm should reconcile the interests of the owner and the tenants, which may be conflicting, and choose between short-term benefits and the long-term value of the property.

To let the property management firm perform its functions efficiently, the property owner shoudl provide a clear-cut specification of goals, conduct comprehensive analysis of the local real estate market, consider the constantly changing legal regulations governing property management, keep direct contact with tenants and create a proper atmosphere of cooperation within the team providing property services (GAWRON 2010, p. 24).

In the case of residential property management, we can indicate two situations in which, on the one side, there is a property management firm, while on the other:

- the owner (co-owners) of the residential property intended for lease,

- the tenants' association.

The owners of residential houses inhabited by them hardly ever contract their management out to specialized firms, but they do so when ceasing to reside there and deciding to rent the property out in whole or in parts (of individual units).

In residential properties, in which the ownership of at least one unit has been set out, a tenants' association is created by virtue of law. The efficient management of a property by tenants' associations, compliant with applicable regulations, requires a management board to be appointed, or the management of shared areas to be entrusted to a specialized firm with a notary act.

\section{Final remarks}

Residential property management is a complex and difficult task, different than managing other types of properties. The specific character of residential property management arises from the legal regulations that residential units are subjected to, and the different kinds of flats in respect to ownership. What is also important here is the performed function, that is the permanent, uninterrupted use of the premises (the residing of users), which requires the continuity of providing specific services (supplies) to the flats.

The conducted research made it possible to identify and, by and large, characterize various institutional forms of residential property management, varied for individual forms of ownership.

However, no research has been undertaken, which would aim at establishing the effectiveness of residential property management with the use of various organizational and legal forms as this goes beyond the research area adopted in the paper. Such research can provide a lot of interesting proposals and postulates with regard to the improvement of residential property management.

\section{References}

BOŃCZAK-KUCHARCZYK E., 2003, Zarządzanie nieruchomościami mieszkaniowymi (Residential Real Estate Managment), Wyd. C.H.Beck, Warszawa.

BOŃCZAK-KUCHARCZYK E., 2008, Zarządzanie nieruchomościami mieszkaniowymi (Residential Real Estate Management, Legal and Organizational Aspects), Aspekty prawne i organizacyjne, Wyd. ABC, Wolters Kluwer Business Warszawa.

CiepIELA M., 2001, Formy komunalnej działalności gospodarczej (Forms of Municipal Business Activity), Przegląd Ustawodawstwa Gospodarczego, No. 6.

GAWRON H., 2010, Podstawy zarządzania nieruchomościami (Foundations of Real Estate Managment), Wyd. UE Poznań.

Gospodarowanie we wspólnocie mieszkaniowej (Management in a Housing Cooperative), 2002, collective work edited by W. Kalinowski, Wyd. ZCO, Zielona Góra.

Housing Co-operatives Act of 15 December 2000, Journal of Laws 2001, No. 4, item 27, (HCA).

KAMIŃSKI M., 2014, Wptyw technologii wykonania budynku na koszty utrzymania nieruchomości (Influence of Building Technology on the Costs of Real Estate Maintenace), Nieruchomości C.H.Beck, No. 10.

LEWANDOWSKI K., 2004, Modele zarządzania nieruchomościa wspólna wspólnoty mieszkaniowej (Models of Housing Cooperative Real Estate Management), Administrator, No. 10. 
LUTY Z., 1992, Finansowe problemy gospodarki mieszkaniami zakładowymi w przedsiębiorstwach uspołecznionych (Financial Problems of Managing Company Housing in State-Owned Companies), Prace Naukowe AE Wrocław, No. 618.

MYCZKOWSKI L., 1997, Housing co-operatives, Wyd. CHBeck Warszawa.

NAJBAR K., 2002, Rola firmy developerskiej w ksztattowaniu zarządu nieruchomości mieszkalnej (Role of Developers in Shaping Housing Real Estate Management), Finanse, Bankowość, Ubezpieczenia, No. 3.

NALEPKA A., 2013, Zarządzanie nieruchomościami jako obszar przedsiębiorczości w Polsce (Real Estate Management as a field of business activity in Poland), (in:) Inwestycje i nieruchomości we współczesnej gospodarce (Investments and Real Estate in the Modern Economy), collective work edited by Krzysztof Marcinek, Wyd. UE Katowice.

NALEPKA A., NAJBAR K., 2007, Rozwój rynku ustug zarządzania nieruchomościami mieszkaniowymi w Polsce (Development of the Service Market for Managing Residential Real Estate in Poland), Studia i Materiały TNN, Vol. 15, No. 1-2.

PAWELEC J., 2003, Jak zarządzać nieruchomościami w gminie (How to Manage Real Estate in a Municipality), Nieruchomości C.H.Beck, No. 2.

PRZYbYlSKi P., 2001, Przejmowanie nieruchomości do zarzadzania (Taking on Real Estate for Management), (in:) Vademecum zarządcy nieruchomości, edited by W.J. Brzeski, Cracow Real Estate Institute Foundation, Kraków.

SZCZEPANIAK R., 2013, Podmiotowość prawna spótki komunalnej (Legal Subjectivity of a Municipal Company), Samorząd Terytorialny, No. 5.

SZELĄGOWSKA A., 2011, Finansowanie społecznego budownictwa mieszkaniowego (Financing Social Residential Housing), CeDeWu.pl Wydawnictwa Fachowe, Warszawa.

The Act on Some Forms of Support for Residential Construction, consolidated text Journal of Laws of 2000, No. 98, item 1070, (ASRC).

The Act on the Ownership of Premises of 24 June 1994, consolidated text, Journal of Laws of 2000 No. 80 , item 903, (AOP).

TURlEj A., 2004, Wspólnota mieszkaniowa (Housing Cooperative), Wydawnictwo C.H. Beck, Warszawa. 